\title{
Impacts of peat fire on soil flora and fauna, soil properties and environmental damage in Riau Province, Indonesia
}

\author{
BASUKI WASIS ${ }^{\natural}$, BAMBANG HERO SAHARJO, ERIANTO INDRA PUTRA \\ Department of Silviculture, Faculty of Forestry, Institut Pertanian Bogor. Jl. Ulin, Dramaga Campus, Bogor 16680, West Java, Indonesia. \\ Tel./fax.: +62-251-8626806, •email: basuki_wasis@yahoo.com
}

Manuscript received: 24 February 2019. Revision accepted: 31 May 2019

\begin{abstract}
Wasis B, Saharjo BH, Putra EI. 2019. Impacts of peat fire on soil flora and fauna, soil properties and environmental damage in Riau Province, Indonesia. Biodiversitas 20: 1770-1775. Land fires set by communities can result in the death of flora and fauna, damage the soil, and cause smoke disasters. In this study, we focused on the burnt community land in Riau Province, where we conducted a soil analysis through purposive sampling to highlight the effect of the fires on the environment. Our findings showed that fires caused a decrease of peat soil thickness of $10-15 \mathrm{~cm}$, and resulted in $100 \%$ mortality of soil flora and fauna. We found a significant increase in the $\mathrm{Ca}$ and soil $\mathrm{pH}$ after a fire, but total microorganisms, total fungi, and soil respiration are found decreased. Our results strongly showed that the soil and environmental damage of burnt peat soil on community land exceeded the minimum criteria to be classified as "environmental damage" as defined by Indonesian Government Regulation No. 4/2001 (PP No 4/2001) for the parameters of bulk density, porosity, $\mathrm{pH}$, organic $\mathrm{C}, \mathrm{N}$, total microorganisms, total fungi, and respiration.
\end{abstract}

Keywords: community land fire, environmental damage, peatland, soil properties

\section{INTRODUCTION}

Forest and land fire significantly affect the quantity and quality of natural resources and ecosystems by reducing the diversity of flora and fauna as a source of germplasm, decreasing soil quality, changing hydrological functions and contributing to climate change. A further dimension is the sensitive political aspect of transboundary smoke [haze] pollution from fires which not only disrupt the environment in Indonesia but also in neighboring countries (Debano et al. 1998; Page et al. 2002; Saharjo 2016; Wasis 2018).

One source of smoke pollution arises from fires on peatland areas which are owned by rural communities. Peat soil classifies as marginal soil, has a low $\mathrm{pH}$, low soil fertility, and is susceptible to disturbances; thus, any effort to increase peatland productivity should take into account strategies to prevent ecosystem damage. Damage to peatland mainly occurs due to tree-felling and canal construction which result in peat soils becoming drier and more flammable (Hardjowigeno 2005; Wibowo 2009; Saharjo et al. 2011)

Peat fires on community land occur mostly during the dry season. In 2014, Riau Province was one of the regions having a large number of fires with 11,272 hotspots-most of which occurred in three districts, namely, Pelalawan, Siak, and Inderagiri Hilir districts. The burning of peatland is generally a practice used for land clearing. So-called slash-and-burn practices for land clearing is preferred because it is cheap and the leftover ash serves as a fertilizer for the peat soil. More research and information dissemination are essential to countercultural practices and public perception regarding the impact of fires on peat soils, as well as the resulting environmental and soil damage.
Research on the impact of community-set land fires on soil properties and environmental damage is severely lacking, which highlights the importance of conducting this study for sustainable peatland management, in particular, to maintain the more prolonged use of peatland. The use of fire in burning the peatland will give a short time benefit in enhancing its soil fertility. However, in the long term, it will bring the detrimental effect to the area such as subsidence that in turn will significantly decrease the life use of peat soil resulted to the failure in obtaining sustainable use of peatland in the end.

Here, we will investigate the impacts of peat fire on the peat soil damage and relate it to the environmental damage criteria based on the Indonesian Government Regulation No 4/2001. Understanding the severe impact of fire to the peat damage will increase the people awareness to avoid the use of fire in opening and preparing the land and therefore, will maintain the more prolonged use of peatland.

\section{MATERIALS AND METHODS}

\section{Place and time of research}

The research activities were carried out at burnt and unburnt community-owned land in three districts in Riau Province, namely, Pelalawan, Siak, and Indragiri Hilir Districts (Figure 1). Field research was carried out from January to December 2014. Statistical analysis of different soil properties and the analysis of soil and environmental damage was carried out from November to December 2018. 


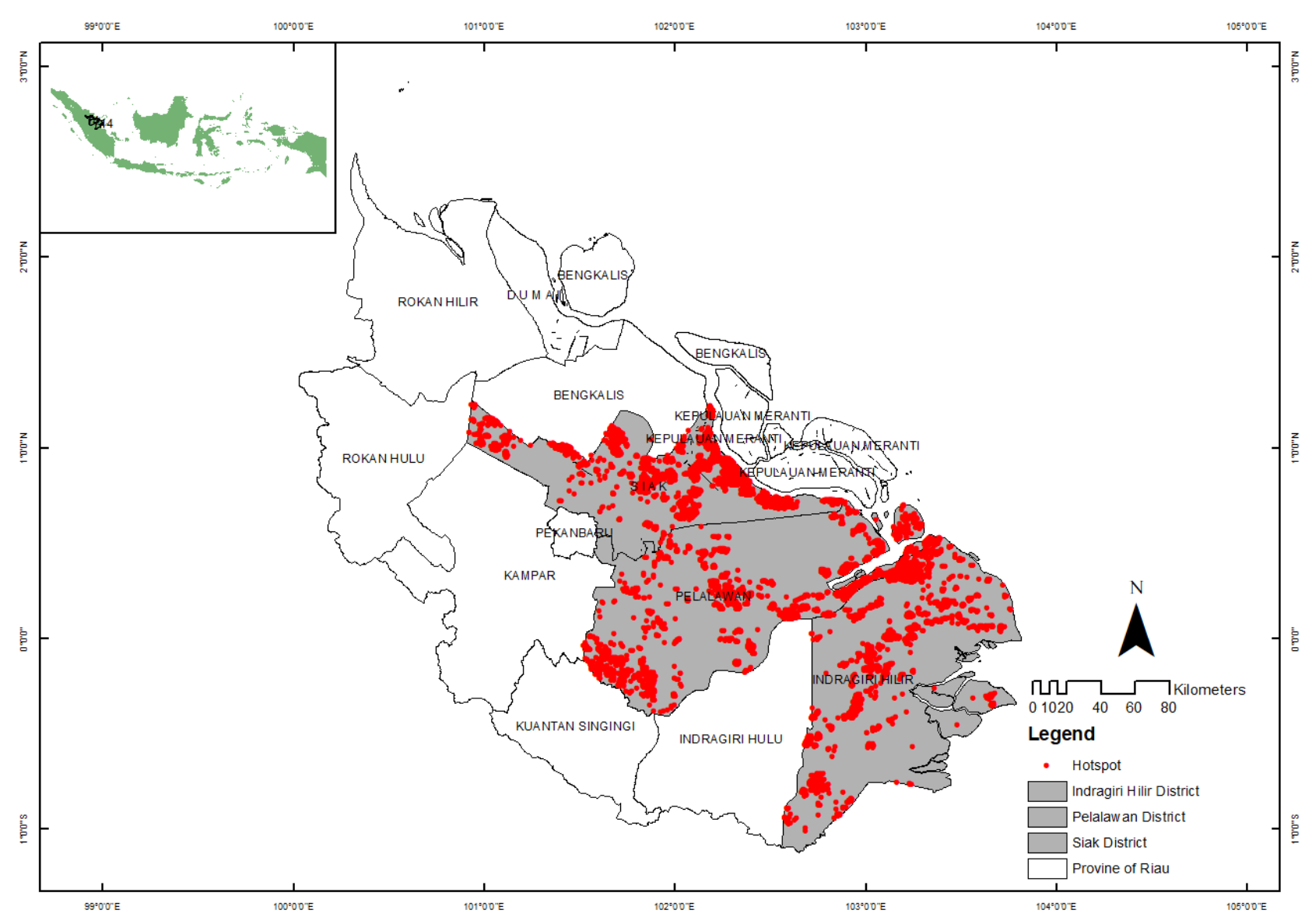

Figure 1. Hotspot distribution in Riau Province, Indonesia 2014

\section{Tools and materials}

The research tools used divided into two groups, namely, data collection tools in the field and nutrient analysis tools in the laboratory. The data collection tools in the field were intact soil samples for composite soil sampling done with hoes, machetes, meter tape, plastic bags, and markers. The primary research materials used were samples of intact soil and composite soil originating from burnt community lands in Pelalawan, Siak and Indragiri Hilir Districts; the two sampling groups represented burnt peat soil and unburnt peat soil. We used the unburnt peat soil as a control parameter. Samples of burnt peat soil were taken 14-30 days after fire occurrences.

\section{Soil sampling and analysis of soil damage}

We used purposive sampling to determine the plot for environmental damage observation. Two observation plots established in each village for burnt peat soil and unburnt peat soil, with three replications each. The sampled soil and collected the burnt understory vegetation within a $20 \times 20$ $\mathrm{m}$ observation plot (Odum 1971). The environmental damage analysis includes subsidence, the mortality of understory, and soil fauna. In each village, the plots for burnt peat soil and unburnt peat soil were located adjacent to each other to maintain the same soil types, topography, and climate (Indonesian Government Regulation No. 4, 2001)

Soil samples for the soil chemical and biological properties were taken purposively at the soil depth of 0-20 $\mathrm{cm}$ from the surface at five places. We composited $1 \mathrm{~kg}$ of soil samples from each site. Soil samples for the physical properties of the soil were conducted on the soil surface at a depth of $0-20 \mathrm{~cm}$ by using a $7 \mathrm{~cm}$ diameter sample ring with a height of $5 \mathrm{~cm}$ (Wasis 2012). The subsidence determined by measuring the lost of peat soil thickness due to fire (PP No. 4/2001). The soil was taken from the field then analyzed at the laboratory. We analyzed bulk density, porosity, available water, and permeability for the physical soil properties. For chemical properties, we analyzed soil $\mathrm{pH}, \mathrm{C}$-organic, $\mathrm{N}, \mathrm{Ca}$, and $\mathrm{Mg}$. Biological properties of the soil analyzed were total microorganisms, phosphorus solvent bacteria, total fungi, and respiration.

\section{Data analysis and analysis of environmental damage}

The variables used for physical soil properties were bulk density, porosity, water availability, and permeability. The variables for soil chemical properties were $\mathrm{pH}, \mathrm{CEC}$, 
C-organic, and nitrogen. Total microorganisms, $\mathrm{P}$ dissolving bacteria, total fungi, and respiration were the variables for soil biological properties. The data analyzed by using an average difference test at a $95 \%$ confidence level (Stell and Torries 1991). Analysis of soil and environmental damage is done based on the guidance stated on The Government Regulation Number 4/2001 on Environmental Damage and or Pollution Control Regarding Forest and or Land Fires.

\section{RESULTS AND DISCUSSION}

\section{General conditions of land fires in Riau Province in 2014}

From 27,364 MODIS Terra/Aqua hotspots detected in Riau Province in 2014, 31\% of them found in Pelalawan, Siak, and Indragiri Hilir Districts, amounting to 2553, 3721, and 2251 hotspots, respectively (Table 1). Therefore, in 2014, these three districts had the highest hotspot density compared to the other districts in Riau Province.

\section{Impact of peat fire on soil flora and fauna, and soil properties}

Damages from forest and land fires are significant both for human life and the lives of other living things. Our field research on burnt community land in Pelalawan, Siak and Indragiri Hilir Districts clearly showed a decrease of the peat soil thickness (subsidence) of 10-15 cm, total death of understory (flora) and soil fauna. In general, the understory (flora) that burned were paku-pakuan (Selaginella wildenowii), kelakai (Stenochlaena palustris), karamunting/harendong (Melastoma malabathricum), rumput gajah (Pennisetum purpureum), pandan (Pandanus

halaeno), orchids (Dendrobium halaenopsis), Eupaturium (Chromolaena odorata), Xyris indica, Calopogonium mucunoides, and others. Common soil animals that burned to death were ants (Formicidae), spiders (Aranaeda), termites (Isoptera), crickets (Gryllidae), grasshoppers (Oxya chinensis), millipedes (Diplopoda), and others. The burned and dried peat soil cannot be restored, and the damages are largely irreversible (Pandjaitan and Hardjoamidjojo 1999; Wibowo 2009). The most devastating result of forest and land fire is the emergence of victims due to direct or indirect fire ferocity, as well as the loss of germplasm and the disappearance of plant and soil fauna species that are unlikely to return (Saharjo 2016; Wasis et al. 2018)

Damage of the peat soil was started from the establishment of the canals and land clearing activities. As a result, peat in the area is becoming irreversible drying and thus there is an inability for the peatland to rewet itself without human intervention (e.g. canal blocking (Sutikno et al, 2018)). Once experiencing a certain level of drought, the damage to peat can become permanent. This results in the volume of peat shrinking, in turn resulting in a decrease in subsidence (Widyati 2011; Wasis 2018). Apart from the reduction in water content, subsidence also occurs due to the shrinkage of peat volume due to the process of decomposition and erosion. In the first two years after peatland was drained, the subsidence rate reached up to 50 $\mathrm{cm}$. In subsequent years, the subsidence rate decreased around 2-6 cm/year depending on the level of peat maturity and the depth of the drainage channel (Agus and Subiksa, 2008).

Burning peat soil removes fuel (biomass) and damages the peat soil. Burning on peat soil will cause a loss of biomass, litter/twigs and peat soil layers, and a decrease in the thickness of peat soil of about 10-30 cm (Wasis 2018). Another impact of burning peat soil is an increase in soil porosity, a decrease in available water content, an increase in soil permeability, a decrease in content weight and a decrease in available water and groundwater (Wasis 2018). The flame temperature of surface fire on the peatland-while lower than other fuel types-still ranges from $800-1150^{\circ} \mathrm{C}$ (Saharjo 2016), resulting in death of flora, fauna, microorganisms and burns the peat soil. Strategies needed to protect peatland from fire include canal blocking and appropriate water management (Wasis and Mulyana 2009; Saharjo et al. 2011; Wasis 2018; Sutikno et al, 2018).

\section{Pelalawan District}

Statistical analysis on the soil properties clearly showed that land fires have a significant impact on soil $\mathrm{pH}, \mathrm{C}$ organic, total microorganisms, phosphorus (P) solvent bacteria, and have a very significant effect on calcium $(\mathrm{Ca})$, magnesium $(\mathrm{Mg})$, total fungi and respiration (Table 2, Figure 2). The burned soil shows a marked increase in soil $\mathrm{pH}$ by $54.39 \%$ and a decrease in C-organic by $3.80 \%$. This study also confirms that land fires may improve soil $\mathrm{pH}$ and fertility of peat soil which explains the traditional application of fire in slash and burn agriculture. Specifically, several studies have determined that burning peat soil typically results in the soil $\mathrm{pH}$ being around 6.33 , which at a neutral $\mathrm{pH}$ level within the range of 6.5-7.5, thus providing plants with the optimal availability of nutrients (Tan 1995; Harjowigeno 2005; Binkley 1987).

The $\mathrm{Ca}$ and $\mathrm{Mg}$ content found in the burnt peat soil increased by $575.23 \%$ and $167.15 \%$, respectively. These results show that peatland fires improved soil fertility due to an increase in metal elements such as $\mathrm{Ca}$ and $\mathrm{Mg}$, thus resulting in favorable growing conditions and eliminates the need for communities to add lime to increase the $\mathrm{pH}$ level of the acidic peat soil.

Table 1. Hotspot distribution in Riau Province, Indonesia 2014

\begin{tabular}{lc}
\hline District & Hotspots \\
\hline Pelalawan & 2,553 \\
Siak & 3,721 \\
Indragiri Hilir & 2,251 \\
Others & 18,839 \\
& \\
Total for Riau Province & 27,364 \\
\hline Source: Forest and Land Fire Laboratory of IPB University
\end{tabular}


While burning of peat soil may have some desirable effects for soil fertility, we also noted the severe consequences including a reduced thickness of peat soils (subsidence) of and average of $10-15 \mathrm{~cm}$, decreased Corganic by $3.80 \%$, a decrease in total microorganisms by $82.72 \%$, decreased total fungi by $77.50 \%$, and respiration was reduced by $68.96 \%$. These results, therefore, may indicate that an increase in soil $\mathrm{pH}$ and fertility of peat soil after fire, could be an ash as a residual from the burning. In sum, burning peat soil causes a decrease in the thickness of the peat soil and the death of the flora and fauna of the soil, as well as the total decline in microorganisms, $\mathrm{P}$ solvent bacteria and total fungi. Peat soils that are damaged by fire indicate the shrinkage and the ability of the soil to store water and nutrients will not return (irreversible) (Buringh 1983; Soepardi 1983; Hardjowigeno 2005).

\section{Siak district}

The results of soil analysis on burnt soil showed that fire significantly impacted $\mathrm{pH}$, calcium, magnesium, total microorganisms, and total fungi, and had a very significant effect on bulk density and respiration (Table 3, Figure 3). Burnt peat soil showed a significant increase in soil $\mathrm{pH}$ by $73.68 \%$ and increased $\mathrm{Ca}$ and $\mathrm{Mg}$ contents by $1586.96 \%$ and $596.88 \%$, respectively.
Fires in peat soil in Siak District reduced its thickness by $10-15 \mathrm{~cm}$, reduced the total microorganism by $55.16 \%$, reduced the total fungi by $78.35 \%$ and reduced respiration by $72.59 \%$. The increase in soil $\mathrm{pH}$ and fertility of peat soils can be explained as the result of residual ash from peat soil combustion. However, the fires caused a significant decrease in the thickness of the peat soil, the death of soil flora and fauna, a decrease in total microorganisms and decrease in total fungi.

An increase in alkali metal elements $(\mathrm{Ca}$ and $\mathrm{Mg}$ ) is another indicator of fire's impact on peat soil. Alkali metal is useful for increasing soil $\mathrm{pH}$ and lowering acidity. The $\mathrm{Ca}$ and $\mathrm{Mg}$ are macro elements needed by plants, where $\mathrm{Ca}$ plays an important role for cell-wall formation in plants, and $\mathrm{Mg}$ is needed in the formation of chlorophyll (leaf green matter) in plants (Hardjowigeno 2005).

\section{Indragiri Hilir District}

The soil analysis of burnt peat soils in Indragiri Hilir District showed significant decrease in total fungi, while the bulk density, $\mathrm{pH}$, total microorganisms, and soil respiration significantly different compared to unburnt soils (Table 4, Figure 4). Burnt peat soil exhibited significantly increased soil $\mathrm{pH}$ by $54.72 \%$. In Indragiri Hilir District, burning the land has improved the fertility of peat soils by significantly increasing the Ca content by $199.48 \%$.

Table 2. Changes of peat soil properties after fires in Pelalawan District, Riau, Indonesia

\begin{tabular}{llll}
\hline Soil properties & Unburnt & Burnt & Change \\
\hline Bulk density $(\mathrm{g} / \mathrm{cm} 3)$ & $0.21 \pm 0.03$ & $0.27 \pm 0.03$ & $+0.06(28.57 \%)$ \\
Porosity $(\%)$ & $89.37 \pm 5.64$ & $83.61 \pm 6.51$ & $-5.76(6.45 \%)$ \\
pH & $4.10 \pm 0.78^{*}$ & $6.33 \pm 0.51$ & $+2.23(54.39 \%)$ \\
C organic $(\%)$ & $55.29 \pm 0.60^{*}$ & $53.19 \pm 0.64$ & $-2.10(3.80 \%)$ \\
Nitrogen $(\%)$ & $2.19 \pm 0.45$ & $1.28 \pm 0.02$ & $-0.91(41.55 \%)$ \\
Calcium $(\mathrm{me} / 100 \mathrm{~g})$ & $5.49 \pm 1.49^{* *}$ & $35.93 \pm 2,65$ & $+31.58(575.23 \%)$ \\
Magnesium (me/100g) & $2.07 \pm 0.05^{* *}$ & $5.53 \pm 0.44$ & $+3.46(167.15 \%)$ \\
Total microorganism $\left(\mathrm{x} 10^{6} \mathrm{cfu}\right)$ & $50.17 \pm 8.25^{*}$ & $8.67 \pm 6.29$ & $-41.50(82.72 \%)$ \\
Total fungi $\left(\mathrm{x} 10^{4} \mathrm{cfu}\right)$ & $20.00 \pm 3.61^{* *}$ & $4.50 \pm 2.50$ & $-15.50(77.50 \%)$ \\
P solvent bacteria $\left(\mathrm{x} 10^{3} \mathrm{cfu}\right)$ & $3.0 \pm 2.00^{*}$ & $0.83 \pm 0.76$ & $-2.17(72.33 \%)$ \\
Respiration $(\mathrm{mgC}-\mathrm{CO} 2 / \mathrm{kg}$ of soil/day) & $27.90 \pm 0,60^{* *}$ & $8.66 \pm 0.22$ & $-19.24(68.96 \%)$ \\
\hline
\end{tabular}

Note: *significant at $95 \%$ confidence interval; **highly significant at $99 \%$ confidence interval

Table 3. Changes in the nature of land on burned community lands in Siak District, Riau, Indonesia

\begin{tabular}{|c|c|c|c|}
\hline Soil properties & Unburnt & Burnt & Change \\
\hline Bulk density $(\mathrm{g} / \mathrm{cm} 3)$ & $0.19 \pm 0.02 * *$ & $0.29 \pm 0.01$ & $+0.10(52.63 \%)$ \\
\hline Porosity $(\%)$ & $90.53 \pm 2.42$ & $85.32 \pm 5.15$ & $-5.21(5.75 \%)$ \\
\hline $\mathrm{pH}$ & $3.80 \pm 0.56^{*}$ & $6.60 \pm 0.10$ & $+2.80(73.68 \%)$ \\
\hline C-organic (\%) & $53.40 \pm 3.80$ & $31.50 \pm 18.60$ & $-21.90(41.01 \%)$ \\
\hline Nitrogen $(\%)$ & $2.26 \pm 0.27$ & $1.14 \pm 0.83$ & $-1.12(49.56 \%)$ \\
\hline Calcium $(\mathrm{me} / 100 \mathrm{~g})$ & $2.3 \pm 2.40^{*}$ & $38.80 \pm 20.0$ & $+36.50(1586.96 \%)$ \\
\hline Magnesium (me/100g) & $0.96 \pm 0.39^{*}$ & $6.69 \pm 2.71$ & $+5.73(596.88 \%)$ \\
\hline Total microorganism $\left(\mathrm{x} 10^{6} \mathrm{cfu}\right)$ & $64.67 \pm 6.01 *$ & $29.0 \pm 9.76$ & $-35.67(55.16 \%)$ \\
\hline Total fungi $\left(\mathrm{x} 10^{4} \mathrm{cfu}\right)$ & $37.00 \pm 10.97 *$ & $8.00 \pm 1.00$ & $-29.00(78.35 \%)$ \\
\hline$P$ solvent bacteria $\left(\times 10^{3} \mathrm{cfu}\right)$ & $1.5 \pm 0.5$ & $0.5 \pm 0.5$ & $-1.00(66.67 \%)$ \\
\hline Respiration (mgC-CO2/kg of soil/day) & $10.8 \pm 0.2 * *$ & $2.96 \pm 0.38$ & $-7.84(72.59 \%)$ \\
\hline
\end{tabular}

Note: *significant at $95 \%$ confidence interval; **highly significant at $99 \%$ confidence interval 
Table 4. Changes in soil properties after fire in community lands in Indragiri Hilir District, Riau, Indonesia

\begin{tabular}{|c|c|c|c|}
\hline Soil properties & Unburnt & Burnt & Change \\
\hline Bulk density (g/cm3) & $0.17 \pm 0.02 * *$ & $0.26 \pm 0.01$ & $+0.09(52.94 \%)$ \\
\hline Porosity $(\%)$ & $83.13 \pm 1.74$ & $81.91 \pm 7.50$ & $-1.22(1.47 \%)$ \\
\hline $\mathrm{pH}$ & $5.30 \pm 0.17 * *$ & $8.20 \pm 0.27$ & $+2.90(54.72)$ \\
\hline C-organic $(\%)$ & $46.60 \pm 10.45$ & $35.35 \pm 9.20$ & $-11.25(24.14 \%)$ \\
\hline Nitrogen $(\%)$ & $2.30 \pm 0.23$ & $1.97 \pm 0.12$ & $-0.33(14.35 \%)$ \\
\hline Calcium (me/100g) & $11.46 \pm 2.81 * *$ & $34.32 \pm 4.45$ & $+22.86(199.48 \%)$ \\
\hline Magnesium (me/100g) & $3.96 \pm 0.73$ & $4.18 \pm 0.72$ & $+0.22(5.55 \%)$ \\
\hline Total microorganism (x $\left.10^{6} \mathrm{cfu}\right)$ & $29.67 \pm 9.50 * *$ & $1.67 \pm 0.76$ & $-28.00(94.37 \%)$ \\
\hline Total fungi $\left(\times 10^{4} \mathrm{cfu}\right)$ & $26.83 \pm 5.60 *$ & $3.98 \pm 2.36$ & $-22.85(85.17 \%)$ \\
\hline $\mathrm{P}$ solvent bacteria $\left(\mathrm{x} 10^{3} \mathrm{cfu}\right)$ & $1.50 \pm 0,5$ & $0.50 \pm 0.50$ & $-1.00(66.67 \%)$ \\
\hline Respiration (mgC-CO2/kg of soil/day) & $29.80 \pm 5.57 * *$ & $2.97 \pm 0.90$ & $-26.83(90.03 \%)$ \\
\hline
\end{tabular}

Note: *significant at $95 \%$ confidence interval; **highly significant at $99 \%$ confidence interval

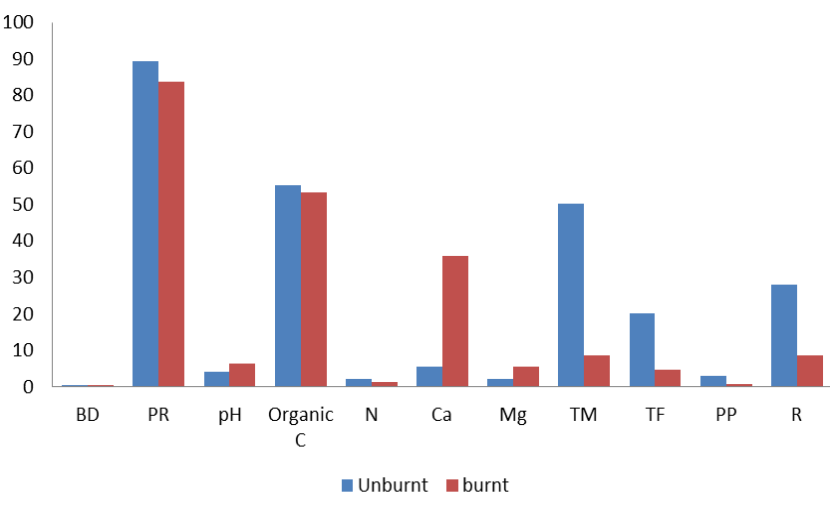

Figure 2. Changes in soil properties after fires in Pelalawan District, Riau, Indonesia. BD (Bulk Density: gram $\left./ \mathrm{cm}^{3}\right)$, PR (Porosiy:\%), pH (pH), C-organic (\%), N (Nitrogen:\%), Ca (calcium: $\mathrm{me} / 100 \mathrm{~g}$ ), $\mathrm{Mg}$ (Magnesium: me/100g), TM (total microorganism: $\times 10^{6} \mathrm{cpu}$ ), TF (total fungi: $\mathrm{x} 10^{4} \mathrm{cpu}$ ), PP (P solvent bacteria: $\mathrm{x} 10^{3} \mathrm{cpu}$ ), $\mathrm{R}$ (respiration: $\mathrm{mgC}-\mathrm{CO}_{2} / \mathrm{kg}$ soil $/$ day)

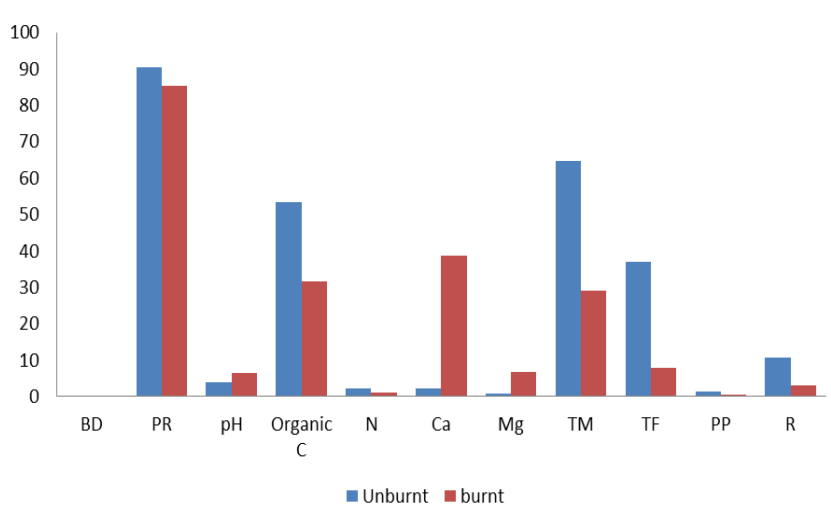

Figure 3. Changes in soil properties after fires in Siak District, Riau, Indonesia. BD (Bulk Density: gram $/ \mathrm{cm}^{3}$ ), PR (Porosiy:\%), $\mathrm{pH}(\mathrm{pH})$, C-organic (\%), N (Nitrogen:\%), Ca (calcium: me/100 g), Mg (Magnesium: me/100g), TM (total microorganism: x $10^{6}$ $\mathrm{cpu}$ ), TF (total fungi: $\times 10^{4} \mathrm{cpu}$ ), PP (P solvent bacteria: $\times 10^{3}$ $\mathrm{cpu}$ ), $\mathrm{R}$ (respiration: $\mathrm{mgC}-\mathrm{CO}_{2} / \mathrm{kg}$ soil/day)

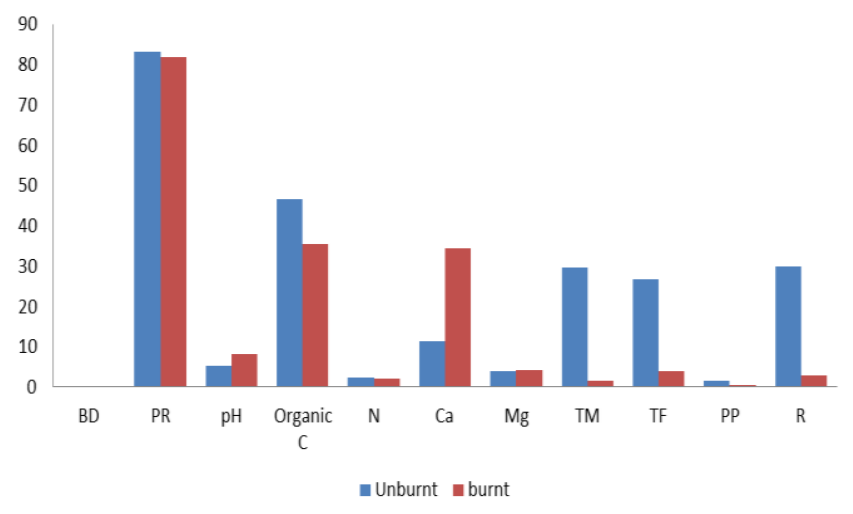

Figure 4. Changes in soil properties after fires in Indragiri Hilir District, Riau, Indonesia. BD (Bulk Density: gram $/ \mathrm{cm}^{3}$ ), PR (Porosiy:\%), pH (pH), C-organic (\%), N (Nitrogen:\%), Ca (calcium: me/100 g), Mg (Magnesium: me/100g), TM (total microorganism: $\times 10^{6} \mathrm{cpu}$ ), TF (total fungi: $\mathrm{x} 10^{4} \mathrm{cpu}$ ), PP (P solvent bacteria: $\times 10^{3} \mathrm{cpu}$ ), $\mathrm{R}$ (respiration: $\mathrm{mgC}-\mathrm{CO}_{2} / \mathrm{kg}$ soil/day)

The soil analysis of burnt peat in Indragiri Hilir showed a reduced thickness of peat soils by $10-15 \mathrm{~cm}$, reduced total microorganism by $94.37 \%$, reduced total fungi by $85.17 \%$ and reduced respiration by $90.03 \%$. Fires also caused a loss of soil microbes and soil biota. Soil heating either kill soil organisms directly or affect reproductive capacity. However, burning the peat soil increased nutrients, thus indirectly increasing the plant growth and microbial proliferation of the soil. The proliferation of soil microbes is generally temporary after nutrient availability decreases and thereafter will decline again after germination (Saharjo 2016; Wasis 2018).

The field observation and laboratory analysis results from the three districts evaluated, strongly support the hypothesis that peatland fires will increase the soil $\mathrm{pH}$ and $\mathrm{Ca}$, but it will significantly reduce total microorganisms, total fungi and respiration. The residual ash from fires proved to be rich in metallic nutrients such as $\mathrm{Ca}, \mathrm{Mg}, \mathrm{K}$ and $\mathrm{Na}$. The negative impacts of fires on the peat soil included loss of subsidence, soil flora and fauna death, and smoke as a pollutant. 
Table 5. Analysis of environmental damage due to land fires in Riau Province, Indonesia

\begin{tabular}{|c|c|c|c|c|}
\hline \multirow{2}{*}{ Soil properties } & \multirow{2}{*}{$\begin{array}{c}\text { Criteria for soil damage } \\
\text { (PP No. 4/2001) }\end{array}$} & \multicolumn{3}{|c|}{ Change/damage (D) } \\
\hline & & Pelalawan & Siak & Indragiri Hilir \\
\hline Bulk density $\left(\right.$ gram $\left./ \mathrm{cm}^{3}\right)$ & $+($ increase $)$ & $+0.06(\mathrm{~d})$ & $+0.10 * *(\mathrm{~d})$ & $+0.09 * *(\mathrm{~d})$ \\
\hline Porosity $(\%)$ & - (decrease) & $-5.76(d)$ & $-5.21(\mathrm{~d})$ & $-1.22(\mathrm{~d})$ \\
\hline $\mathrm{pH}$ & + (increase) & $+2.23^{*}(\mathrm{~d})$ & $+2.80 *(\mathrm{~d})$ & $+2.90 * *(d)$ \\
\hline C-organic (\%) & - (decrease) & $-2.10 *(d)$ & $-21.90(\mathrm{~d})$ & $-11.25(\mathrm{~d})$ \\
\hline Nitrogen $(\%)$ & - (decrease) & $-0.91(d)$ & $-1.12(d)$ & $-0.33(d)$ \\
\hline Total microorganism $\left(\mathrm{x} 10^{6} \mathrm{cpu}\right)$ & - (decrease) & $-41.50 *(d)$ & $-39.00 *(d)$ & $-28.00 * *(\mathrm{~d})$ \\
\hline Total fungi $\left(\mathrm{x} 10^{4} \mathrm{cpu}\right)$ & - (decrease) & $-15.50 * *(\mathrm{~d})$ & $-29.00 *(d)$ & $-22.85 *(d)$ \\
\hline Respiration (mgC-CO $/$ /kg soil/day) & - (decrease) & $-19.24 * *(\mathrm{~d})$ & $-7.84 * *(d)$ & $-26.83 * *(\mathrm{~d})$ \\
\hline
\end{tabular}

Note: *significant at $95 \%$ confidence interval; **highly significant at $99 \%$ confidence interval ; d: environmental damage (PP No. $4 / 2001)$

Based on soil analysis at the three locations, the cost to preserve/restore the peat soils, including the needed soil treatments of compost, fertilizer and lime for planting oil palm on non-combustion peatlands, is estimated at US\$ 4,369.2 to 5,352.6 per ha. This is in line with the result from Herman et al. (2009) which estimates that the cost of oil palm plantations construction on peatland was US\$ 4,771.666 per ha.

\section{Environmental damage analysis}

Pursuant to PP No. 4/2001, our study proved that there had been environmental damage in the community land areas after fire occurrences at all of the study areas in Pelalawan, Siak, and Indragiri Hilir Districts. We have cataloged environmental damage for bulk density, porosity, $\mathrm{pH}, \mathrm{C}$-organic, $\mathrm{N}$, total microorganisms, total fungi and respiration (Table 5).

In conclusion, the peatland fires on the community land in Riau Province reduced the peat soil thickness by 10-15 $\mathrm{cm}$, and brought the total death of soil flora and fauna. There was a significant increase in soil $\mathrm{pH}$ and $\mathrm{Ca}$. Significant decreases of total microorganisms, total fungi, and soil respiration are found after the fire. Our results sharply conclude that the changes in bulk density, porosity, $\mathrm{pH}$, organic $\mathrm{C}, \mathrm{N}$, total microorganisms, total fungi, and respiration in burnt peat soil on community land fulfills the standard criteria for environmental damage by Government Regulation Indonesia No. 4/2001 (PP No 4/2001).

\section{ACKNOWLEDGEMENTS}

We thank the Forest Ecology Laboratory, Forest Influence Laboratory, and Forest and Land Fire Laboratory of IPB University, Bogor, Indonesia. Without their help and support, this research would not have been possible.

\section{REFERENCES}

Agus F, Subiksa IGM. 2008. Lahan Gambut: Potensi untuk Pertanian dan Aspek Lingkungan. Balai Penelitian Tanah dan World Agroforestry Centre (ICRAF), Bogor, Indonesia.

Binkley D. 1987. Forest Nutrition Management. Duke University, Durham, NC, USA.
Buringh P. 1983. Pengantar Pengajian Tanah-tanah Wilayah Tropika dan Subtropika. Gadjah Mada University Press. Yogyakarta. [Indonesian]

Debano LF, Neary DG, Ffolliott PF. 1998. Fire's Effect on Ecosystems. John Wiley and Sons, Inc. New York.

Hardjowigeno S. 2005. Ilmu Tanah. Akademika Pressindo. Jakarta. [Indonesian]

Herman, Agus F, Las, I. 2009. Analisa Finansial dan Keuntungan yang hilang dari pengurangan emisi karbon dioksida pada perkebunan kelapa sawit. Jurnal Litbang Pertanian 28 (4): 127-133. [Indonesian]

Odum EP. 1971. Fundamentals of Ecology. W.B. Saunders Co. Philadelphia.

Page S, Siegert F, Rieley JO, Boehmn HDV, Jaya A, Limin S. 2002. The amount of carbon released from peat and forest fire in Indonesia during 1997. Nature 42: 61-65.

Pandjaitan NP, Hardjoamidjojo. 1999. Study of physical nature of peatland in relation to drainage for agricultural land. Buletin Keteknikan Pertanian 13 (3) : 87-96

Saharjo BH. 2016. Pengendalian Kebakaran Hutan dan atau Lahan Indonesia. PT Penerbit IPB Press. Bogor. [Indonesian]

Saharjo BH, Wasis B. 2006. Do we need to protect our natural resources? Adv Earth Sci 21 (2): 178-182.

Saharjo BH, Wasis B, Mulyana D. 2011. Canal Blocking of Burn Peat Swamp Forest and Its Future. 5th International Wildland Fire Conference: Poster Session, South Africa.

Soepardi G. 1983. Sifat dan Ciri Tanah. Fakultas Pertanian, IPB, Bogor. [Indonesian]

Soerianegara I, Indrawan A. 2005. Ekologi Hutan Indonesia. Departemen Manajemen Hutan, Fakultas Kehutanan IPB, Bogor. [Indonesian]

Sorensen KW. 1992. Human Action to Control Global Warming Through Designed Ecosystems. UNESCO/ROSTEA publication, New York

Stell RGD, Torries JH. 1991. Principles and Procedures of Statistic A. Biometrical Approach. PT Gramedia Pustaka Utama Jakarta. [Indonesian]

Sutikno S, Nasrul B, Gunawan H, Jayadi R, Rinaldi, Saputra E, Yamamoto K. 2018. The effectiveness of canal blocking for hydrological restoration in tropical peatland. ICAnCEE 2018. DOI: $10.1051 /$ matecconf/201927606003

Tan KH. 1995. Environmental Soil Science. Marcel Dekkker Inc. New York.

Wasis B, Mulyana D. 2009. Carbon Content at Several Vegetation Type in Ex-PLG Million ha after 10 Years Burnt. Proceedings of IPB research Seminar. Bogor

Wasis B. 2012. Soil properties in natural forest destruction and conversion to agricultural land in Gunung Leuser National Park, North Sumatera Province. Jurnal Managemen Hutan Tropika 18 (3): 206-212

Wasis B, Winata B, Marpaung DR. 2018. Impact of land and forest fire on soil fauna diversity in several land cover in Jambi Province, Indonesia. Biodiversitas 10 (2): 740-746.

Wasis B. 2018. Impact on peatland canal blocking of soil properties in the ex PLG million ha of Central Kalimantan Province. Adv Res Agric Vet Sci: 5 (3): 4-11.

Wibowo A. 2009. Role of peatland to global climate change. Tekno Hutan Tanaman 2 (1): 19-28.

Widyati E. 2011 Kajian optimasi pengelolaan lahan gambut dan isu perubahan iklim. Tekno Hutan Tanaman 4 (2): 57-68. 